\title{
EXTRAFISCALIDADE: RECUPERAÇÃO AMBIENTAL POR MEIO DA CIDE COMBUSTÍVEL
}

\section{EXTRAFISCALITY: ENVIRONMENTAL RECOVERY THROUGH CIDE FUEL}

\author{
EWERTON RICARDO MESSIAS \\ Doutorando e Mestre em Direito pela UNIMAR - Universidade de Marília - Brasil \\ Professor da Universidade de Marília - UNIMAR \\ ewerton_messias@hotmail.com \\ MARIA DE FÁtIMA RIBEIRO \\ Pós-Doutora em Direito Fiscal pela Universidade de Lisboa, \\ Professora do Programa de Mestrado e Doutorado em Direito da UNIMAR - \\ Universidade de Marília - Brasil \\ professoramariadefatimaribeiro@gmail.com
}

Recibido: 13 de febrero de 2019 / Aceptado: 15 de mayo de 2019

RESUMO: $O$ presente artigo tem por objetivo analisar se a CIDE COMBUSTÍVEL no Brasil pode revelar-se como um campo fértil para o financiamento de projetos e programas voltados à recuperação de Áreas de Preservação Permanente, como forma de cumprir com a finalidade constitucional e legal para a qual tal o tributo foi criado. Assim, são investigados o conceito de extrafiscalidade; a tributação e a intervenção do Estado na economia; a existência de um estado de caos ambiental; a importância das Áreas de Preservação Permanente para a mitigação do caos ambiental; e a CIDE COMBUSTÍVEL. O método de abordagem a ser seguido será o empíricodialético, utilizando-se das pesquisas bibliográfica e legislativa, tendo como sistema de referência uma combinação da Teoria da Complexidade de com o 
Law and Economics. Em conclusão, aponta-se que a adequada destinação dos recursos da CIDE COMBUSTíVEL para o financiamento de projetos e programas de recuperação de Áreas de Preservação Permanente, poderia redundar no cumprimento da finalidade ambiental do tributo, tornando sua exigência legal, além de contribuir para um dos objetivos do novo Código Florestal brasileiro, qual seja recuperar as Áreas de Preservação Permanente em todo o território nacional.

ABSTRACT: The purpose of this article is to analyze if the CIDE FUEL in Brazil can prove to be a fertile field for the financing of projects and programs aimed at the recovery of Permanent Preservation Areas, as a way to comply with the constitutional and legal purpose for which such tribute was created. Thus, the concept of extrafiscality is investigated; taxation and state intervention in the economy; the existence of a state of environmental chaos; the importance of Permanent Preservation Areas for the mitigation of environmental chaos; and CIDE FUEL. The method of approach followed will be the empirico-dialectic, using bibliographical and legislative research, having as a reference system a combination the Theory of Complexity with Law and Economics. In conclusion, it is pointed out that the adequate allocation of CIDE FUEL funds for the financing of projects and programs for the recovery of Permanent Preservation Areas could result in compliance with the environmental purpose of the tax, making its legal requirement, besides contributing to a of the objectives of the new Brazilian Forest Code, which is to recover the Permanent Preservation Areas throughout the national territory.

RESUM: L'objectiu d'aquest article és analitzar si el combustible CIDE al Brasil pot resultar ser un camp fèrtil per al finançament de projectes i programes destinats a la recuperació d'àrees de preservació permanent, com a manera de complir amb el propòsit constitucional i legal pel qual es va crear aquest tribut. Per tant, s'investiga el concepte d'extrafiscalitat; la fiscalitat i la intervenció de I'Estat en l'economia; l'existència d'un estat de caos ambiental; la importància de les àrees de preservació permanent per a la mitigació del caos ambiental; i 
el combustible CIDE. El mètode d'enfocament seguit serà l'empiricodialèctic, mitjançant la recerca bibliogràfica i legislativa, que tingui com a sistema de referència una combinació de la teoria de la complexitat amb el dret i l'economia. Com a conclusió, es destaca que l'assignació adequada dels fons del combustible CIDE per al finançament de projectes i programes per a la recuperació d'àrees de preservació permanent podria resultar en el compliment de l'objectiu ambiental de l'impost, fent el seu requisit legal, a més de contribuir a un dels objectius del nou Codi Forestal brasiler, que és recuperar les àrees de preservació permanent al territori nacional.

RESUMEN: El propósito de este artículo es analizar si el combustible CIDE en Brasil puede ser un campo fértil para el financiamiento de proyectos y programas destinados a la recuperación de áreas de preservación permanente, como una forma de cumplir con el propósito legal y constitucional para el cual tal tributo fue creado. Así, se investiga el concepto de extrafiscalidad; tributación e intervención estatal en la economía; la existencia de un estado de caos ambiental; la importancia de las áreas de preservación permanente para la mitigación del caos ambiental; y el combustible CIDE. El método de enfoque seguido será el empiricodialéctico, utilizando la investigación bibliográfica y legislativa, teniendo como sistema de referencia una combinación de la teoría de la complejidad con el derecho y la economía. En conclusión, se señala que la asignación adecuada de los fondos del combustible CIDE para el financiamiento de proyectos y programas para la recuperación de áreas de preservación permanente podría resultar en el cumplimiento del propósito ambiental del impuesto, haciendo su requerimiento legal, además de contribuir a uno de los objetivos del nuevo Código Forestal brasileño, que es recuperar las áreas de preservación permanente en todo el territorio nacional.

PALAVRAS-CHAVE: Extrafiscalidade - Caos ambiental - Área de Preservação Permanente - CIDE COMBUSTÍVEL - Recuperação ambiental. 
KEYWORDS: Extrafiscality - Environmental chãos - Permanent Preservation Area - CIDE FUEL - Environmental recovery.

PARAULAS CLAUS: Extrafiscalitat - Caos ambiental - Àrea de preservació permanent - Combustible CIDE — Recuperació ambiental.

PALABRAS CLAVE: Extrafiscalidad - Caos ambiental - Área de preservación permanente - Combustible CIDE - Recuperación Ambiental.

SUMÁRIO: I. Introdução. II. Extrafiscalidade e políticas públicas. III. O estado de caos ambiental e a necessidade de medidas mitigadoras. IV. As áreas de preservação permanente e sua importância para a mitigação do estado de caos ambiental instalado. V. CIDE combustível: instrumento de mitigação das externalidades negativas do setor econômico de importação e comercialização de petróleo e de seus derivados. VI. A destinação dos recursos da CIDE combustível para a recuperação das áreas de preservação permanente. VII. Conclusão. VIII. Bibliografia.

\section{INTRODUÇÃO}

O desenvolvimento industrial, ocorrido durante os séculos XIX e XX, causou inúmeras implicações positivas e negativas na sociedade, advindas dos impactos transfronteiriços experimentados em nível mundial.

O desenvolvimento científico e tecnológico resultou em alteração de comportamento econômico, social e ambiental, pois a sociedade passou a não encontrar limites de contentamento, de forma a impor um ritmo acelerado de consumismo global, o qual, aliado à crescente busca pelo lucro, por parte da iniciativa privada, contribui sobremaneira para a instalação de um verdadeiro caos ambiental, cujos efeitos são experimentados em nível mundial, por meio das mudanças climáticas e da escassez de água potável, entre outros problemas ambientais mundiais.

A ampliação dos riscos ambientais na sociedade pós-moderna, devido a sua desconsideração ou má gestão, propicia o surgimento de novos desafios, que orientam a busca de formas de mitigação do caos ambiental instalado.

O presente artigo, pautado nessas premissas, tem por objetivo analisar se os recursos arrecadados por meio da CIDE COMBUSTÍVEL (Contribuição de intervenção no domínio econômico incidente sobre as operações realizadas com 
combustíveis) podem revelar-se como um campo fértil para o financiamento de projetos e programas voltados à recuperação de Áreas de Preservação Permanente, como forma de cumprir com a finalidade constitucional e legal para a qual tal tributo foi criado e, ao mesmo tempo, contribuir para a mitigação do estado de caos ambiental instalado.

Inicialmente busca-se analisar o conceito $e$ as características da extrafiscalidade, visando verificar se ela pode se revelar como um instrumento de efetivação dos objetivos e dos fundamentos da República Federativa do Brasil.

Em seguida, analisa-se o poder de tributação e de intervenção do Estado no domínio econômico, visando verificar quando e quais os limites para o Estado exercer tal poder.

Adiante, pesquisa-se acerca da existência de um estado de caos ambiental instalado e a necessidade de sua mitigação, como forma de garantir a fruição do direito fundamental a um meio ambiente ecologicamente equilibrado.

Analisa-se, ainda, a importância do restabelecimento das funções ambientais das Áreas de Preservação Permanente para a mitigação do caos ambiental, restabelecimento, este, a ser viabilizado por meio da recuperação ambiental de tais áreas, o que contribuiria, também, para o sequestro e a fixação do dióxido de carbono encontrado livre na atmosfera.

Por fim, busca-se verificar se a CIDE COMBUSTÍVEL pode revelar-se como instrumento de mitigação das externalidades negativas produzidas pelo setor econômico de produção de petróleo e seus derivados, e, desta forma, pode ser considerada como um instrumento apto a mitigar o caos ambiental instalado.

Para a obtenção dos resultados almejados pela pesquisa, o método de abordagem a ser seguido será o empírico-dialético ${ }^{1}$, utilizando-se das pesquisas bibliográfica e legislativa, tendo como sistema de referência uma

\footnotetext{
1 Para Lourival Vilanova, "os objetos culturais, entre os quais se aloja o direito, são todos aqueles que estão na experiência, tendo existência real, contudo sempre valiosos, positiva ou negativamente. $\mathrm{O}$ ato gnosiológico próprio é a "compreensão" e o método da correspondente ciência é o "empírico-dialético"”. (VILANOVA, 2008, p.82)
} 
combinação da Teoria da Complexidade ${ }^{2}$ de Edgar Morin com o Law and Economics de Richard A. Posner ${ }^{3}$.

\section{EXTRAFISCALIDADE E POLÍTICAS PÚBLICAS}

A partir de uma concepção restritiva, a extrafiscalidade pode ser entendida como a utilização do tributo como instrumento de política financeira. Nesse aspecto, Geraldo Ataliba afirma que "consiste a extrafiscalidade no uso de instrumentos tributários para obtenção de finalidades não arrecadatórias, mas estimulantes, indutoras ou coibidoras de comportamentos, tendo em vista outros fins, a realização de outros valores constitucionalmente consagrados" (ATALIBA, 1990, p.233).

Diante desta concepção restritiva, a extrafiscalidade pode redundar em aumento ou perda de numerário, caso haja aumento ou diminuição das alíquotas e/ou da base de cálculo dos tributos, respectivamente (CARRAZZA, 2008, p.109).

No entanto, o presente trabalho desenvolver-se-á sobre as bases da concepção ampla do que seja extrafiscalidade. Para tal concepção a extrafiscalidade agrega-se à fiscalidade, revestindo o tributo de uma finalidade constitucional e/ou legal para que possa atuar no campo das ciências política, econômica, social, ambiental etc. Diante da concepção ampla, a extrafiscalidade não se limita meramente a estimular, induzir ou coibir comportamentos, como também não visa a apenas objetivos econômicos, mas também políticos, culturais, ambientais, dentre outros (TORRES, 2001, p.167).

\footnotetext{
2 A ciência da dinâmica não linear, ou teoria da complexidade, propõem-se a ligar as mais variadas disciplinas, como a física, a biologia, a química, a economia, o direito, a sociologia, as engenharias etc., na busca do equilíbrio do qual o estado de caos distancia-se. (MORIN, 2001, pp.199-200).

${ }^{3} \mathrm{~A}$ análise econômica do direito, como atualmente existe não só nos Estados Unidos mas também na Europa, que tem a sua própria associação de direito e economia florescente, tem aspectos positivos (que é descritivo) e aspectos normativos. Ela tenta explicar e prever o comportamento dos participantes e nas pessoas reguladas pela lei. Ela também tenta melhorar a aplicação da lei por chamar a atenção para aspectos em que as leis existentes ou propostas têm consequências não intencionais ou indesejáveis, quer sobre a eficiência econômica ou a distribuição do rendimento e da riqueza, ou outros valores. Ela não é uma simples empresa de marfim, pelo menos nos Estados Unidos, onde o movimento de direito e economia é entendido por ter influenciado a reforma jurídica num certo número de áreas importantes. [...] Análise econômica do direito é geralmente considerada o desenvolvimento mais significativo no pensamento jurídico nos Estados Unidos desde o desaparecimento do realismo jurídico há meio século. (POSNER, 1998, p.2) (Texto em inglês no original).
} 
Esta concepção ampla do que seja extrafiscalidade permite identificá-la não somente na incidência tributária voltada a estimular, induzir ou coibir comportamentos, mas também na destinação específica do produto arrecadado pelas chamadas Contribuições de Intervenção no Domínio Econômico - CIDE, as quais não buscam estimular ou coibir comportamentos, mas sim realizar diretamente valores constitucionais, de acordo com as finalidades constitucionais e/ou legais que justificam a sua criação. Daí as afirmativas do professor Hugo de Brito Machado Segundo: "o tributo é extrafiscal quando seu objetivo principal é a interferência no domínio econômico, para buscar um efeito diverso da simples arrecadação de recursos financeiros" (SEGUNDO, 1997, p. 129).

A doutrina espanhola aponta três características da extrafiscalidade. Nesse sentido, Cavalcante, citando Martinez De Pisón, aponta que:
"Poder-se-iam, por tanto, reduzir a três as características básicas da extrafiscalidade, o caráter extra-orcamentário, ao não se incluir no orçamento do Estado; a gestão, por estar encomendada a órgãos diferentes da Administração financeira; e a afetação, as exações extrafiscais são receitas que nascem afetadas a um fim, isto é, desde o momento de sua criação podem estar adstritas a determinadas finalidades específicas" (MARTÍNEZ DE PISÓN apud CAVALCANTE, 2012, pp. 172-173). ${ }^{4}$ (tradução nossa).

A Constituição Federal brasileira, em que pese haver adotado a valorização do trabalho e a livre iniciativa como fundamentos da ordem econômica constitucional, permite a intervenção do Estado na economia. Nesse sentido, Casalta Nabais disserta que a norma tributária extrafiscal tem o "[...] intuito de actuar directamente sobre os comportamentos económicos e sociais de seus destinatários" (NABAIS, 1998, p.629), revelando-se como uma forma de intervenção do Estado no domínio econômico.

\footnotetext{
${ }^{4}$ Se podrían por tanto, reducir a tres las características básicas de la parafiscalidad, el carácter extrapresupuestario, al no incluirse en el presupuesto del Estado; la gestión, por estar encomendada a órganos diferentes de la Administración financiera; y la afectación, las exacciones parafiscales son ingresos que nacen afectados a un fin, esto es, que desde el momento de su recaudación pueden estar adscritos a determinadas finalidades específicas.
} 
No entanto, tal intervenção deve ser admitida quando para garantir a efetividade dos princípios da função social da propriedade, da defesa do consumidor, da defesa do meio ambiente, da redução das desigualdades regionais e sociais e do tratamento favorecido para as empresas de pequeno porte constituídas sob as leis brasileiras e que tenham sua sede e administração no País, previstos no Art. 170, incisos III, V, VI, VII e IX, respectivamente. Portanto, a intervenção do Estado na economia é admitida quando para garantir a justiça social e as liberdades individuais. Desta forma, como ensina Maria de Fátima Ribeiro, "os agentes econômicos não podem agir livremente no mercado" (RIBEIRO, 2012, pp. 207-208).

O Art. 1ํㅡㄹ inciso I, da Constituição Federal de 1988, prevê a dignidade da pessoa humana como um dos fundamentos da República Federativa do Brasil, estando, seus objetivos, previstos no seu artigo $3^{\circ}$.

No Art. 170, caput, a Constituição Federal de 1988 expõe o objetivo da ordem econômica constitucional, qual seja "assegurar a todos existência digna, conforme os ditames da justiça social", tendo por fundamento a valorização do trabalho humano e a livre iniciativa.

No inciso IV, do mesmo Art. 170, a Constituição Federal de 1988, prevê o princípio da livre concorrência, o qual, segundo Maria de Fátima Ribeiro, "[...] pressupõe igualdade de condições para os agentes econômicos, sendo essencial para dar proteção ao mercado", assim “[...] cabe ao Estado Democrático de Direito reprimir o abuso de poder econômico que vise à dominação dos mercados, à eliminação da concorrência e ao aumento arbitrário dos lucros (art. 173, § 4.ํ)” (RIBEIRO, 2012, p. 216).

A defesa do meio ambiente também é prevista como um dos princípios que informam a livre iniciativa, visando assegurar a todos uma existência digna, conforme se pode verificar da interpretação do Art. 170, caput e inciso VI, da Constituição Federal de 1988.

Importante salientar que o Estado, no exercício do direito de tributar, deve observar o princípio da subordinação, segundo o qual cabe ao Estado intervir na economia, não para substituir os agentes econômicos da sua organização e exploração, mas sim para manter o equilíbrio, evitar o abuso do poder 
econômico etc., enfim, para evitar que a economia se disperse dos interesses e objetivos primários do Estado Democrático (DALLAZEM; LIMA JÚNIOR, 2008, p. 326).

A Constituição Federal de 1988 inovou em relação às anteriores, ao prever, no Art. 149, uma espécie tributária específica (denominada de contribuição) para a intervenção direta e explícita do Estado no domínio econômico. Essa forma de intervenção direta da tributação foi reafirmada com a Emenda Constitucional $n^{\circ} 42$, de 2003, ao se inserir no artigo 146-A previsão para que lei complementar estabeleça critérios especiais de tributação com vistas a prevenir desequilíbrios da concorrência, sem prejuízo da competência da União para estabelecer normas com igual desiderato (DALLAZEM; LIMA JÚNIOR, 2008, p. 327).

Verifica-se que a tributação não se presta única e exclusivamente ao custeio das atividades estatais, pois, também "desempenha papel relevante no que se refere às condições para o desenvolvimento econômico" (SILVA, 2006, p.189) ou, melhor dizendo, para o desenvolvimento nacional sustentáve ${ }^{5}$, justamente focando a extrafiscalidade (DALLAZEM; LIMA JÚNIOR, 2008, p. 328), de forma a influenciar as decisões econômicas, políticas e ambientais dos agentes, por meio do binômio custo benefício (FERRAZ, 2006, p. 345).

A extrafiscalidade será efetivada na prática mediante a elaboração de políticas públicas visando atender às finalidades constitucionais. Tais políticas são bem-vindas, mas toda a sociedade é também responsável pelo desenvolvimento e pelas próprias políticas. Se estas não estiverem aliadas a outros movimentos ou comportamentos da própria comunidade, não haverá a efetivação das políticas estabelecidas. Para a qualidade de vida e o desenvolvimento sustentável, é necessário que um conjunto de informações seja efetivamente tratado.

\footnotetext{
5 O desenvolvimento nacional sustentável é reconhecido como um dos fundamentos da República Federativa do Brasil a partir da interpretação sistemática dos artigos $33^{\circ}$, II; 170, VI e 225, caput, da Constituição Federal de 1988. Conforme Paulo Caliendo e Veyzon Muniz, "o desenvolvimento nacional sustentável encontra-se igualmente previsto no artigo $1^{\circ}$ da Lei $\mathrm{n}$. 12.349, de 15 de dezembro de 2010, que alterou o artigo 3 o da Lei de Licitações e estabeleceu que a licitação destina-se "a promoção do desenvolvimento nacional sustentável". Sendo o primeiro diploma legal brasileiro a trazer expressamente o termo." (CALIENDO; MUNIZ, 2015, pp.158-159)
} 
A extrafiscalidade pode ser implementada pelo Estado brasileiro, com base nas políticas públicas por meio da instituição e a gradação de tributos, pela concessão de isenções e de incentivos fiscais, associados à possibilidade de reduzir as despesas efetuadas pelos contribuintes que utilizem recursos para a preservação ambiental. Sendo assim, a utilização de tributos com caráter ambiental é capaz de fomentar a adoção de uma postura ambientalmente correta (NUNES; AZEVEDO, 2010, p. 5).

Portanto, a extrafiscalidade revela-se como um instrumento ímpar de efetivação dos fundamentos e objetivos da República Federativa do Brasil, e deve operar para garantir a observância dos princípios constitucionais em prol da construção de uma sociedade livre, justa e solidária, em um ambiente de desenvolvimento nacional sustentável e de erradicação da pobreza e da marginalização, visando à justiça social, com a redução das desigualdades sociais e regionais, como forma de garantir a fruição de uma vida digna de ser vivida.

A intervenção do Estado na interação do Direito Econômico com o Direito Ambiental é feita por meio de políticas públicas que asseguram o planejamento e a organização para alcançar suas finalidades, como uma qualidade de vida para toda sociedade e seu desenvolvimento sustentável (MAGANHINI, 2016, p. 92).

Quais as possibilidades de as normas fiscais interferirem nas políticas públicas ambientais? Os estados contemporâneos têm o desafio de transformar as diretrizes teóricas sobre o desenvolvimento sustentável em políticas públicas coerentes e eficientes. Não há como "definir uma só política pública internacional, considerando as especificidades de cada país, mas é possível criar políticas públicas locais e regionais com base em um conceito comum de sustentabilidade internacional, traçando princípios que sejam o senso comum da humanidade" (PAYÃO; RIBEIRO, 2016, pp. 292-293).

É preciso que o meio ambiente seja preservado, não através de uma tributação acentuada e sim com estímulos ou benefícios, entre eles destacando-se aqueles projetos que contemplam planejamentos ambientais que preservem e recuperem o meio ambiente degradado. Somente serão constitucionais os incentivos fiscais que buscarem 0 equilíbrio do 
desenvolvimento sócio econômico ambiental entre as diferentes regiões do país.

A defesa do meio ambiente é um valor constitucional fundamental inerente com a dignidade da pessoa humana e também com o desenvolvimento econômico e social.

Compete, assim, aos Poderes públicos o desenvolvimento de políticas públicas que viabilizem o gozo dos direitos fundamentais. Nesse sentido, a garantia ao meio ambiente saudável pressupõe uma efetivação estatal.

\section{O ESTADO DE CAOS AMBIENTAL E A NECESSIDADE DE MEDIDAS MITIGADORAS}

Com o crescimento industrial, houve avanços científicos e tecnológicos que resultaram em uma alteração de comportamento econômico, social e ambiental, pois a sociedade passou a não encontrar limites de contentamento, encontrando-se em um ritmo acelerado de consumismo global, o qual, aliado à crescente busca pelo lucro, levada a efeito pelas empresas, desconsiderandose qualquer contexto social, contribuiu sobremaneira para a instalação de uma verdadeira desordem ou caos ambiental.

Importante esclarecer que o caos é caracterizado pelo distanciamento da ordem - desordem - ou do equilíbrio - desequilíbrio -, assim, o caos ambiental é caracterizado pelo desequilíbrio ambiental.

O aumento expressivo da exploração dos recursos naturais não renováveis e a geração, sem controle adequado, de resíduos sólidos, efluentes líquidos e emissões gasosas, provenientes das indústrias e residências, redundaram no caos ambiental, externalizado na forma de desequilíbrios ambientais, os quais foram e vem sendo experimentados de maneira transnacional, como as mudanças climáticas e a escassez de água potável de fácil acesso, entre outros desequilíbrios ambientais mundiais. De igual modo, a Professora Thaís Maganhini escreveu com propriedade:

"O meio ambiente tem sofrido gravíssimas ameaças de extinção de seus recursos com aumento da degradação desenfreada que o 
homem ocasiona com seu desenvolvimento econômico e social. Assim, a própria natureza está dando seu sinal de esgotamento e da escassez de recursos, ocasionando o comprometimento da vida, pelo fato de que não existe vida sem meio ambiente conservado e sadio". (MAGANHINI, 2016, p. 155)

As mudanças climáticas, perceptíveis por meio da alteração dos regimes de chuva, do aumento da intensidade dos furacões, do aumento do nível dos oceanos, dentre outros fenômenos, têm relação direta com o aquecimento global e este tem se agravado em virtude da ausência de incorporação substancial da variável ambiental nos processos decisórios dos Estados e da iniciativa privada, fato que impede ou pelo menos dificulta a adoção de medidas adequadas e efetivas para a redução das emissões de gases de efeito estufa, produzidos por processos produtivos voltados tão somente ao desenvolvimento econômico, em detrimento do desenvolvimento social e da proteção do equilíbrio ambiental, onde há a contínua internalização dos lucros pelos ricos, seguida, da também contínua, socialização dos riscos ambientais e sociais.

As diversas Conferências realizadas para discussão dos efeitos das mudanças climáticas, ainda não chegaram a um resultado prático satisfatório, visto que seu maior resultado, o Protocolo de Quioto, mostrou-se insuficiente para o cumprimento da meta de redução de emissões de gases de efeito estufa, pois, segundo o relatório elaborado pelo Programa das Nações Unidas para o Meio Ambiente, a estimativa de emissões globais de gases de efeito estufa em 2010 foi aproximadamente $14 \%$ maior do que o que deveríamos registrar em 2020 (UNEP, 2012, p.1).

Com relação à questão da escassez de água potável de fácil acesso, importante salientar que o planeta Terra possui cerca de 1,6 bilhões de $\mathrm{Km}^{3}$ de água, dos quais aproximadamente 1,35 bilhões de $\mathrm{Km}^{3}$ é de água salgada, 29 milhões de $\mathrm{Km}^{3}$ é de água doce congelada nas geleiras e calotas, 8,6 milhões de $\mathrm{Km}^{3}$ é de água doce nos continentes e sob eles, e 13 mil $\mathrm{Km}^{3}$ estão na forma de vapor de água na atmosfera (JÚNIOR; HERNANDEZ, 2001, p. 3). 
Assim, $75 \%$ da superfície da terra é coberta por água. No entanto, $97,5 \%$ da água, existente na terra, é salgada; $2,5 \%$ se encontram nas calotas polares, as quais são consideradas as reservas mais puras do planeta, porém sua exploração não é viável; $0,7 \%$ encontram-se nos lençóis subterrâneos; e apenas $0,007 \%$ da água existente no planeta estão nos rios e lagos (JÚNIOR; HERNANDEZ, 2001, p. 3).

Com as alterações no clima a provocar um grande desequilíbrio na distribuição das chuvas, a capacidade dos ecossistemas em recompor suas reservas tem sido prejudicada, de forma a refletir um distanciamento do equilíbrio ambiental, revelando um estado de caos ambiental. Com isso, cresce o risco de aumentar a desertificação no mundo, enquanto em regiões tradicionalmente ricas para a agricultura, como o Brasil, não conseguem mais manter uma produção estável.

No Brasil a divisão da água ainda é desigual em relação aos usos e às responsabilidades de cada setor. A agricultura fica com cerca de $70 \%$ da água captada em córregos, aquíferos e lagos (FAO, 2011, p. 3), usada muitas vezes sem o devido cuidado em relação às técnicas de irrigação, além de deixar escorrer novamente para os cursos d'água uma grande quantidade de produtos utilizados como fertilizantes e defensivos agrícolas. Na verdade, venenos que precisarão ser retirados, em seu próximo uso, em estações de tratamento que vão enviar água encanada às residências e indústrias.

A escassez de água no mundo é agravada pela desigualdade social e pela falta de manejo e usos sustentáveis dos recursos naturais. Segundo o Fundo das Nações Unidas para a Infância (UNICEF) "[...] pelo menos $11 \%$ da população mundial, correspondente a 783 milhões de pessoas, continua a não ter acesso à água potável segura, e milhares de milhões de pessoas continuam sem ter acesso a meios de saneamento" (BRASIL, UNICEF, 2012). De acordo com a UNICEF, "dos 783 milhões de pessoas no mundo sem acesso à água potável melhorada, 119 milhões vivem na China; 97 milhões, na Índia; 66 milhões, na Nigéria; 36 milhões, na República Democrática do Congo; e 15 milhões, no Paquistão" (BRASIL, UNICEF, 2013).

As diferenças registradas entre os países desenvolvidos e os em desenvolvimento demonstram que a crise mundial dos recursos hídricos está diretamente ligada às desigualdades sociais, ou seja, ao distanciamento do 
equilíbrio social, revelando, novamente, um estado de caos. Há regiões com índices críticos de disponibilidade d'água, "[...] como nos países do Continente Africano, onde a média de consumo de água por pessoa é de dezenove metros cúbicos/dia, ou de dez a quinze litros/pessoa" (COMPANHIA AMBIENTAL DO ESTADO DE SÃO PAULO, [2007?]). Por outro lado, "[...] em Nova York, há um consumo exagerado de água doce tratada e potável, onde um cidadão chega a gastar dois mil litros/dia" (COMPANHIA AMBIENTAL DO ESTADO DE SÃO PAULO, [2007?]). A UNICEF alerta que

"Apesar de atualmente $87 \%$ da população mundial (quase 5,9 bilhões de pessoas) ter acesso a uma fonte melhorada de água potável, o risco de poluição da água continua, muitas vezes devido a fatores ambientais, como a crescente urbanização, industrialização e problemas de saneamento" (BRASIL, UNICEF, 2010).

A exploração dos recursos naturais, o descarte de resíduos sólidos, a emissão de efluentes líquidos e a emissão de gases de efeito estufa, sem limites científicos aptos a evitar o esgotamento dos recursos naturais e a poluição, ou seja, sem limites científicos aptos a garantir o equilíbrio ambiental, gerou uma situação fática de desequilíbrio ambiental, ou seja, de caos ambiental.

A manutenção deste comportamento pelos seres humanos, somada à desigualdade social - distanciamento do equilíbrio social -, foi aumentando a distância entre $O$ atendimento das necessidades humanas e o equilíbrio ambiental, de forma a gerar uma situação de caos ambiental, caracterizada pelo desequilíbrio - distanciamento do equilíbrio ambiental -, o qual tem externalizado-se de várias formas, como na poluição do ar, da água e dos solos, na escassez da água potável de fácil acesso, no fenômeno do aquecimento global, na perda da biodiversidade e no esgotamento de jazidas minerais.

A existência de uma vida digna de ser vivida ${ }^{6}$ pela atual e pelas futuras gerações depende da adoção de medidas mitigadoras do estado de caos ambiental instalado, para que o equilíbrio ambiental possa ser restaurado e,

6 Vida digna é aquela vivida com dignidade, sendo, a dignidade, entendida como um fim material, um objetivo, "[...] que se concretiza no acesso igualitário e generalizado aos bens" (saúde, segurança, meio ambiente ecologicamente equilibrado, educação, entre outros) "[...] que fazem com que a vida seja "digna" de ser vivida" (FLORES, 2009, p.37). 
assim, o direito fundamental de fruição de um meio ambiente ecologicamente equilibrado possa ser garantido.

Destas considerações, pode-se verificar que continua sendo um grande desafio, na ordem econômica, a implementação do princípio constitucional do desenvolvimento sustentável. Por isso mesmo, é possível afirmar que as questões ambientais estão interligadas com as questões econômicas e sociais, e que a efetividade da proteção ambiental depende do tratamento globalizado, envolvendo as políticas ambientais de âmbito nacional, bem como de ações regionais do Estado e a participação da sociedade.

\section{AS ÁREAS DE PRESERVAÇÃO PERMANENTE E SUA IMPORTÂNCIA PARA A MITIGAÇÃO DO ESTADO DE CAOS AMBIENTAL INSTALADO}

Em relação às mudanças climáticas, à perda da biodiversidade e à escassez da água potável de fácil acesso, há que se abordar a importância da recuperação das Áreas de Preservação Permanente (APP) dos recursos hídricos, como as nascentes, os olhos d'água e os cursos d'água, dentre outras previstas no artigo 4ํㅡㄹ da Lei no $12.651 / 12$, para a mitigação de tais problemas ambientais mundiais, os quais externalizam o caos ambiental vivenciado na pós-modernidade.

A recuperação da biodiversidade nestas áreas visa propiciar o restabelecimento de sua "[...] função ambiental de preservar os recursos hídricos, a paisagem, a estabilidade geológica e a biodiversidade, facilitar o fluxo gênico de fauna e flora, proteger o solo e assegurar o bem-estar das populações humanas", conforme preconizado no artigo $3^{\circ}$, inciso II, da Lei $n^{\circ}$ 12.651/12. Além de contribuir, por meio do processo da fotossíntese, para o sequestro do dióxido de carbono da atmosfera, um dos principais gases responsáveis pelo agravamento do efeito estufa.

Neste sentido, "[...] as APP, dada à importância de suas funções ambientais e de segurança, fazem-se presentes nas leis ambientais, em nível federal, desde 1934" (MESSIAS, [2017a?]), visto que havia previsão de sua proteção já no Código Florestal de 1934, o qual, assim como os Códigos Florestais que o sucederam (Lei no 4.771/65 e da Lei ํㅜ 12.651/12), reconhecia as Áreas de 
Preservação Permanente "como bem de interesse comum a todos habitantes do País, sendo, o exercício do direito de propriedade, limitado pelas disposições contidas em tal Lei" (MESSIAS, [2017a?]).

Desde 1934, as Áreas de Preservação Permanente sempre estiveram sobre a tutela da legislação florestal brasileira, em virtude da importância de suas funções ambientais para garantia da qualidade ambiental e, por via de consequência, para garantia do equilíbrio ambiental, este, imprescindível para a existência de vida digna de ser vivida.

A proteção das Áreas de Preservação Permanente está contida, então, no poder/dever do Poder Público e da coletividade de proteger o equilíbrio ambiental, visando garantir o direito à fruição de um meio ambiente ecologicamente equilibrado, como condição sine qua non à existência de vida digna de ser vivida, para as presentes e futuras gerações, conforme o contido no previsto no artigo 225, caput, da Constituição Federal de 1988.

A proteção ambiental não pode sofrer retrocessos, pois, qualquer retrocesso na proteção do equilíbrio ambiental, representaria, por via de consequência, um retrocesso em matéria de dignidade da pessoa humana, vez que comprometeria a fruição do direito a um meio ambiente ecologicamente equilibrado e, com isso, comprometeria a existência de uma vida digna de ser vivida. Neste sentido:

"Ao concretizar o direito fundamental ao meio ambiente ecologicamente equilibrado no caput, do artigo 225, da Constituição Federal de 1988, o constituinte vinculou-se ao que foi garantido, não Ihe sendo permitido, a partir de então, retroceder na tutela já oferecida, de forma a conceder menos proteção do que a oferecida até então" (MESSIAS, 2017b, p. 85).

Desta forma, revela-se de extrema importância a indução, por parte do Estado brasileiro, à recuperação das Áreas de Preservação Permanente de recursos hídricos, como forma de mitigação do caos ambiental instalado.

Neste aspecto, a Contribuição de Intervenção no Domínio Econômico - CIDE pode se revelar como importante instrumento de indução apto a mitigar o caos ambiental instalado, ao menos no que se refere à recuperação das Áreas de 
Preservação Permanente de recursos hídricos, visando à mitigação das mudanças climáticas, da escassez de água potável de fácil acesso e da perda da biodiversidade, por meio do restabelecimento das funções ambientais de tais áreas.

A CIDE é uma espécie tributária dotada de uma nítida função extrafiscal, vez que se caracteriza como instrumento de intervenção no domínio econômico à disposição da União para utilização nos casos autorizados pela Constituição Federal de 1.988. Trata-se, assim, de um tributo interventivo constitucional, cuja finalidade é intervir em diversos setores econômicos, visando à correção das falhas de mercado.

No que se refere à CIDE, é importante salientar que, diversamente do que fez com os demais tributos, a Constituição Federal de 1.988 não declinou quais devem ser suas hipóteses de incidência, indicando, tão somente, quais finalidades que referido tributo deve perseguir.

Há, então, clara vinculação do exercício da competência tributária ao cumprimento do objeto constitucional, fato que caracteriza a CIDE como um tributo finalístico, conforme se verá adiante.

Em razão de corte metodológico, será analisada a seguir a CIDE COMBUSTÍVEL, objetivando-se verificar a sua aptidão para o cumprimento de uma das suas finalidades, qual seja o financiamento de projetos ambientais relacionados à produção de petróleo e de seus derivados, mormente, projetos ou programas ambientais que visem à recuperação das Áreas de Preservação Permanente de recursos hídricos.

\section{CIDE COMBUStíVEL: INSTRUMENTO DE MITIGAÇÃO DAS EXTERNALIDADES NEGATIVAS DO SETOR ECONÔMICO DE IMPORTAÇÃO E COMERCIALIZAÇÃO DE PETRÓLEO E DE SEUS DERIVADOS}

A CIDE COMBUStíVEL ou Contribuição de Intervenção no Domínio Econômico sobre importação e comercialização de petróleo e seus derivados, de competência da União, está prevista inicialmente no Art. 149 e no Art. 177, da Constituição Federal de 1988, o qual, em seu §4ำ, prevê os elementos da 
sua hipótese de incidência e suas finalidades bem como a sua destinação. No âmbito infraconstitucional a CIDE COMBUSTÍVEL foi instituída pela Lei no 10.336/01 e regulamentada pela Lei $n$ o 10.636/02.

Ela tem como fato gerador a importação e a comercialização no mercado interno brasileiro de gasolinas; diesel; querosene de aviação e demais querosenes; óleos combustíveis; gás liquefeito de petróleo, inclusive o derivado de gás natural e de nafta, álcool etílico combustível; os hidrocarbonetos líquidos derivados de petróleo e os hidrocarbonetos líquidos derivados de gás natural utilizados na produção de gasolinas ou de diesel, segundo as normas estabelecidas pela Agência Nacional do Petróleo, conforme o contido no Art. 177, §4ํㅡㄹ da Constituição Federal de 1988, combinado com o Art. $2^{\circ}$, incisos I a VI e parágrafo único, da Instrução Normativa SRF № 422, de 17 de maio de 2004.

É contribuinte da CIDE COMBUSTÍVEL a pessoa física ou jurídica que produza, importe ou formule qualquer dos produtos citados no Art. $2^{\circ}$, da Instrução Normativa SRF № 422/2004, conforme previsão contida no Art. 3ํㅡ, da mesma Instrução Normativa, bem como aquele que adquirir qualquer dos citados produtos de procedência estrangeira, no caso de importação realizada por sua conta e ordem, por intermédio de pessoa jurídica importadora, oportunidade em que será considerado contribuinte solidário, nos termos parágrafo único, do Art. 3ํㅡㄹ da Instrução Normativa SRF № 422/2004.

A quantidade dos produtos referidos no Art. $2^{\circ}$, importados ou comercializados no mercado interno, expressa nas unidades de medida constantes dos Anexos I e II, da Instrução Normativa SRF № 422/2004, compõem a base de cálculo da CIDE-COMBUSTÍVEL.

No que se refere às alíquotas máximas é importante explicitar que a Instrução Normativa SRF № 422/2004, fixou a alíquota máxima da CIDE-COMBUSTÍVEL no caso de gasolinas e de hidrocarbonetos líquidos derivados de gás natural utilizados exclusivamente na produção de gasolina, ou na produção de diesel e gasoline, em $R \$ 280,00$ (duzentos e oitenta reais) por metro cúbico (m3). E, no caso de diesel e de hidrocarbonetos líquidos derivados de gás natural utilizados exclusivamente na produção de diesel, fixou a alíquota máxima em $\mathrm{R} \$ 70,00$ (setenta reais) por m3, conforme previsão contida no Art. 10, incisos I 
e II; e § 2º, incisos I e II (BRASIL, 2004).

Neste sentido, de 30 de abril de 2004 a 01 de maio de 2008, o Decreto oㅡ 5.060 fixou a alíquota da gasolina em $R \$ 280,00$ (duzentos e oitenta reais) por metro cúbico (m3), e a do diesel em $\mathrm{R} \$ 70,00$ (setenta reais) por m3, zerando as demais (BARSIL, 2004). No período de 02 de maio de 2008 a 07 de junho de 2009, o Decreto № 6.446 alterou a alíquota da gasolina para $R \$ 180,00$ (cento e oitenta reais) por metro cúbico (m3), e a do diesel em $\mathrm{R} \$ 30,00$ (trinta reais) por $\mathrm{m} 3$, mantendo zeradas as demais (BRASIL, 2008). De 08 de junho de 2009 a 04 de fevereiro de 2010, o Decreto № 6.875, novamente alterou as alíquotas, fixando a alíquota da gasolina em $R \$ 230,00$ (duzentos e trinta reais) por metro cúbico (m3), e a do diesel em $R \$ 70,00$ (setenta reais) por m3, mantendo zeradas as demais (BRASIL, 2009). No ano de 2010, o Decreto $n^{\circ}$ 7.095 reduz a alíquota da gasolina para $R \$ 150,00$ (cento e cinquenta reais) por metro cúbico (m3), no periodo de 05 de fevereiro de 2010 a 30 de abril de 2010 , restabelecendo o valor da referida alíquota para $R \$ 230,00$ (duzentos e trinta reais) por metro cúbico (m3), no período compreendido entre 01 de maio de 2010 a 26 de setembro de 2011 (BRASIL, 2010). Entre 27 de setembro de 2011 e 31 de outubro de 2011, o Decreto № 7.570 reduziu a a alíquota da gasolina para $R \$ 192,00$ (cento e noventa e dois reais) por metro cúbico (m3) (BRASIL, 2011). Com a edição do Decreto oㅜ 7.591, houve a redução da alíquota da gasolina para $\mathrm{R} \$ 91,00$ (noventa e um reais) por metro cúbico (m3), e a do diesel para $R \$ 47,00$ (quanrenta e sete reais) por m3 (BRASIL, 2011). No ano de 2012,com a edição do Decreto № 7.764 todas as alíquotas foram zeradas no período compreendido entre 26 de junho de 2012 e 30 de abril de 2015 (BRASIL, 2012). Em 01 de maio de 2015, o Decreto oo 8.395 fixa a alíquota da gasolina em $\mathrm{R} \$ 100,00$ (cem reais) por metro cúbico (m3), e a do diesel em $\mathrm{R} \$ 50,00$ (cinquenta reais) por $\mathrm{m} 3$, alíquotas que se mantêm até a atualidade (BRASIL, 2015).

Importante salientar que as alíquotas da CIDE-COMBUSTíVEL aplicáveis a querosene de aviação, demais querosenes, óleos combustíveis com alto teor de enxofre, óleos combustíveis com baixo teor de enxofre, gás liquefeito de petróleo, inclusive o derivado de gás natural e de nafta e álcool etílico combustível, foram reduzidas a zero, conforme $\S 1^{\circ}$, do Art. 10, da Instrução 
Normativa SRF № 422/2004.

No que se refere à apuração da CIDE COMBUSTíVEL ela será mensal, quando incidir na comercialização no mercado interno; e por apuração, quando incidente na importação e quando da aquisição no mercado interno ou da importação de nafta pela central petroquímica para a produção da gasolina, conforme previsão contida no Art. 11, da Instrução Normativa SRF № 422/2004.

O caráter intervencionista da contribuição tem fundamento no Art. 149, da Constituição Federal e advém da dupla função da qual pode ser observado 0 Estado-Regulador e o Estado-Executor. Isto é, aquele que "se incumbe de estabelecer as regras disciplinadoras da ordem econômica com o objetivo de ajustá-las aos ditames da justiça social” (CARVALHO FILHO, 2009, p. 867) e aquele que explora a atividade econômica, de forma direta ou indireta, através de seus órgãos ou pessoas jurídicas a ele vinculadas.

Neste ponto, importante se faz esclarecer que "as contribuições são exigências que se qualificam pela finalidade visada com sua instituição, portanto, elas existem não porque algo ocorreu, mas para que algo se obtenha" (GRECO, 2001, p. 18). Portanto, a CIDE COMBUSTÍVEL representa um instrumento tributário voltado à realização das finalidades previstas na Constituição Federal de 1988 e na Lei ํㅜ 10.336/01, ou seja, a espécie tributária em questão, apesar do caráter fiscal e extrafiscal, se vincula de forma absoluta à sua finalidade, de modo que, em havendo ato legislativo que contrarie a afetação, ocorrerá sua inconstitucionalidade.

Desta forma, sua constitucionalidade material é vinculada às finalidades que motivaram a sua criação (PIMENTA, 2001, p. 181) ), quais sejam o pagamento de subsídios a preços ou transporte de álcool combustível, gás natural e seus derivados e derivados de petróleo; o financiamento de projetos ambientais relacionados com a indústria do petróleo e do gás; e o financiamento de

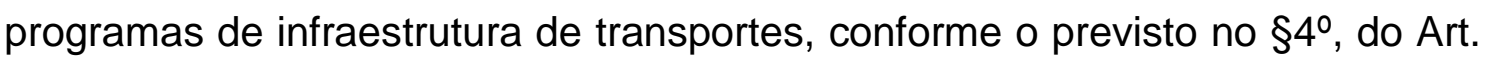

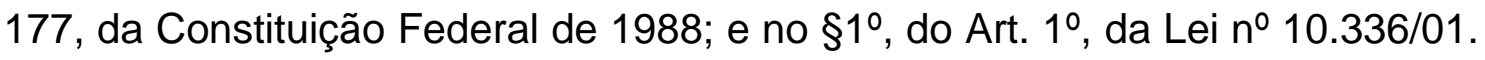
Trata-se, portanto, de clara autorização constitucional e legal para intervenção do Estado na economia, mais especificamente de autorização para que a União possa intervir no setor econômico de transações de petróleo e de seus 
derivados, por meio da instituição de um tributo (PACE, 2011, p. 117), visando à concretização das finalidades previstas no $\S^{4^{\circ}}$, do artigo 177 , da Constituição Federal de 1988; e no $\S 1^{\circ}$, do artigo 1ํ, da Lei ํㅜ 10.336/01, dentre elas 0 financiamento de projetos ambientais relacionados com a indústria do petróleo e do gás.

O financiamento de projetos ambientais relacionados com a indústria do petróleo e do gás, enquanto uma das finalidades da CIDE COMBUSTíVEL visa à mitigação das falhas de mercado propiciadas pelo setor econômico de comercialização de petróleo e de seus derivados, mais especificamente das externalidades negativas ${ }^{7}$ reveladas nos riscos $^{8}$ e danos ambientais ${ }^{9}$ decorrentes de tal setor econômico.

Por tal motivo, Karlo Eric Galvão Dantas afirma que "[...] a referida finalidade encontra respaldo no texto constitucional, a fim de tributar os agentes poluidores, de forma a custear a diminuição da poluição e a reparação por danos porventura causados ao meio ambiente" (DANTAS, 2008, p. 28).

Pode-se afirmar, desta forma, que a CIDE COMBUSTÍVEL encontra-se vinculada às finalidades interventivas previstas no texto constitucional e legal, as quais estão relacionadas às correções das falhas de mercado decorrentes das atividades econômicas desenvolvidas pelo setor de importação e de comercialização de petróleo e de seus derivados, o que justifica a intervenção

\footnotetext{
7 Para Paulo Caliendo "as externalidades referem-se ao conceito criado pelos economistas Marshall e Celil Pigou para se referirem aos efeitos e consequências dos atos dos agentes econômicos, dentre os quais se incluem o governo. Estes efeitos podem ser benéficos ou prejudiciais, dependendo de como se realizem. Assim, trata-se de temas relacionados à economia e não diretamente ao Direito. O sistema jurídico recebe estas informações e as processa em sua linguagem própria, característica da normatividade jurídica" (CALIENDO, 2014, p. 64) (grifo do autor). Denominam-se como externalidades os efeitos colaterais da produção de bens ou da prestação de serviços sobre terceiros, os quais não estão diretamente envolvidos com a atividade. Nesse aspecto, o aumento da lucratividade, da disponibilidade de vagas de trabalho e da proteção dos recursos ambientais revela-se como externalidades positivas. No entanto, a ocupação irregular de territórios indígenas, o aumento expressivo da exploração desregrada dos recursos naturais não renováveis e a geração sem controle adequado de resíduos sólidos, efluentes líquidos e emissões de gases de efeito estufa provenientes dos mais variados processos produtivos e de consumo revelam-se como externalidades negativas.

8 Pode-se entender o risco ambiental como a combinação da probabilidade de ocorrência de um evento ou exposição perigosa com a gravidade do dano ambiental que pode ser causado por tal evento ou exposição perigosa (MESSIAS; SOUZA, 2015, pp. 198-199).

9 Pode-se entender o dano ambiental como sendo qualquer lesão ou alteração negativa do meio ambiente, ocorrida em virtude de evento natural ou de ação antrópica lícita ou ilícita, que afeta diretamente o ser humano em sua saúde, segurança, atividades sociais e econômicas (MESSIAS; SOUZA, 2015, p. 203).
} 
do Estado na Economia, por meio de sua exigência, desde que os recursos arrecadados sejam destinados à concretização de tais finalidades constitucionais e legais (MASCITTO, 2013, pp. 97-98).

Portanto, com a instituição da CIDE COMBUSTíVEL, o constituinte derivado objetivou evitar a socialização das externalidades negativas decorrente da importação e da comercialização de petróleo e de seus derivados, visando a mitigar tal falha de mercado por meio da internalização dos custos dos danos ambientais, juntamente com o lucro obtido na exploração da atividade econômica.

O financiamento de projetos ambientais relacionados com a indústria do petróleo e de seus derivados, por meio da CIDE COMBUSTíVEL, alinha-se, portanto, ao objetivo da República Federativa do Brasil de propiciar um desenvolvimento nacional sustentável, conforme preconizado pela Constituição Federal de 1988, em seus artigos 3o, 170 e 225.

\section{A DESTINAÇÃO dOS RECURSOS DA CIDE COMBUSTíVEL PARA A RECUPERAÇÃO DAS ÁREAS DE PRESERVAÇÃO PERMANENTE}

Como visto, a vinculação dos recursos arrecadados por meio da CIDE COMBUSTÍVEL às finalidades previstas nos textos constitucional e legal é requisito de validade para sua exigência ${ }^{10}$.

No entanto, os recursos arrecadados pelo Poder Público por meio da CIDE COMBUSTÍVEL não têm atingido integralmente as finalidades para as quais o referido tributo foi criado (MASCITTO, 2013, p. 106), pois uma boa parcela de tais recursos foi utilizada para despesas administrativas não previstas dentre tais finalidades constitucionais e legais (DANTAS, 2008, p. 39). Neste sentido, Andrea Mascitto afirma que:

“[...] no período investigado (de 2002 a 2011), forma gastos apenas de $44,3 \%$ a $86,3 \%$ dos valores arrecadados a título de CIDECombustível, já descontados os $20 \%$ referentes aos recursos da

10 A Lei de Responsabilidade Fiscal (LC no 101/2000) que determina que "os recursos legalmente vinculados a finalidade específica serão utilizados exclusivamente para atender ao objeto de sua vinculação, ainda que em exercício diverso daquele em que ocorrer o ingresso" (Art. 8ํㅡ, Parágrafo único). 
DRU (Desvinculação das Receitas da União - dinheiro que o Estado está autorizado a gastar em outras finalidades diferentes das estabelecidas para as contribuições) e, dentre os valores gastos, uma alta taxa (superior à metade do total da disponibilidade) foi direcionada especialmente para o custeio das despesas correntes de diversos ministérios, tais como dívidas por contrato, indenizações e restituições, material de consumo, diárias, contribuições e obrigações tributárias, empréstimos, auxílio-alimentação, auxíliotransporte e benefícios assistenciais e previdenciários, dentre outros" (MASCITTO, 2013, p. 106).

Tendo em vista o anúncio feito pela Petrobrás de aumento de 7,83\% no preço da Gasolina A na refinaria e de 3,94\% no valor do Diesel, no dia 26 de junho de 2012, foi editado o Decreto o 7.764, o qual zerou as alíquotas da CIDE COMBUSTÍVEL (BRASIL, 2012), visando evitar que tal aumento chegasse a impactar os consumidores finais. As alíquotas somente foram restabelecidas em 01 de maio de 2015, oportunidade em que foram fixadas alíquotas de $R \$$ 100,00 (cem reais) para a gasolina e $R \$ 50,00$ (cinquenta reais) para o diesel, por $\mathrm{m}^{3}$ (metro cúbico) (BRASIL, 2015). Assim, de 26 de junho de 2012 a 30 de abril de 2015 não houve arrecadação com a CIDE COMBUSTÍVEL, não havendo, desta forma, destinação de recursos. A partir de 01 de junho de 2015 com o restabelecimento das alíquotas, verificou-se a continuidade de um direcionamento ainda alto dos valores arrecadados para subsidiar custos não ligados às finalidades constitucionais da CIDE COMBUSTÍVEL, como o custeio das despesas correntes de diversos ministérios e Secretarias dos Estados e do Distrito Federal, tais como dívidas por contrato, indenizações e restituições, material de consumo, diárias, contribuições e obrigações tributárias, empréstimos, auxílio-alimentação, auxílio-transporte, dentre outros.

Com o desvio dos recursos, ou seja, com a não integralização completa dos recursos, há clara inobservância ao contido no Art. 177, §4º, inciso II, da

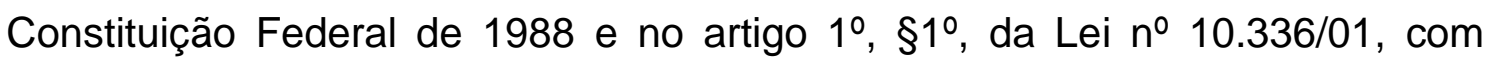
violação, portanto, das regras de competência que condicionam a criação do 
respectivo tributo ${ }^{11}$.

Com isso, torna-se ilegal a sujeição do contribuinte ao seu pagamento, vez que o montante exigido não está sendo integralmente utilizado para os fins que justificaram a criação do tributo, desta forma há o rompimento do "[...] imprescindível liame que deve existir entre a causa autorizativa do tributo e sua destinação" (BARRETO, 2011, p. 165).

No entanto, tal situação de ilegalidade pode ser revertida, por exemplo, com a destinação dos recursos da CIDE COMBUSTíVEL para a recuperação de Áreas de Preservação Permanente, destinação que atende ao princípio da legalidade, vez que perfeitamente alinhada à finalidade prevista no Art. 177, $\S 4^{\circ}$, inciso II, da Constituição Federal de 1988 , e no artigo $1^{\circ}$, $\S^{1}$, da Lei $n^{\circ}$ $10.336 / 01$.

O financiamento de um projeto ambiental com tal viés teria por base a emissão de gases de efeito estufa promovido por meio da queima do petróleo e de seus derivados, principalmente o dióxido de carbono. Neste aspecto, a recuperação das Áreas de Preservação Permanente propiciaria, além do restabelecimento de suas funções ambientais, conforme abordado em item anterior, a criação de sumidouros de dióxido de carbono, pois os conjuntos de árvores plantadas para recuperar tais áreas atuariam, durante toda a sua fase de desenvolvimento, para a captura e fixação do dióxido de carbono existente na atmosfera, vez que, por meio do processo da fotossíntese, as árvores capturam o dióxido de carbono da atmosfera e o fixam em sua estrutura vegetal, devolvendo oxigênio à atmosfera.

Como exemplo de programa que poderia contar com o fomento dos recursos advindos da CIDE COMBUSTíVEL, pode-se citar o Programa Nascentes, o qual se trata de uma ação do Governo do Estado de São Paulo, cuja meta

11 O Professor Eurico Diniz de Santi, coordenou pesquisas realizadas pelo Núcleo de Tributação e Finanças Públicas da FGV. Tais pesquisas partiram de um ponto comum: verificar se o Poder Público está empregando corretamente, na execução orçamentária, os recursos arrecadados nestas contribuições, nos termos das determinações constitucionalmente previstas. Foram eleitos como objetos desse estudo a Contribuição Provisória sobre Movimentação Financeira - CPMF e a Contribuição de Intervenção no Domínio Econômico CIDE Combustíveis, entre os anos de 2002 a 2006. A metodologia utilizada foi consultar o orçamento da União, por meio do programa "Siga Brasil" do Senado Federal, que gera relatórios sobre a execução das despesas públicas em um dado período (SANTI, 2008, pp. 9$10)$. 
inicial é recuperar 4.464 hectares de matas ciliares ${ }^{12}$, por meio da realização de reflorestamentos com aproximadamente 6,3 milhões de mudas de espécies de árvores nativas, tendo por finalidade recuperar as função ambiental das Áreas de Preservação Permanente dos recursos hídricos paulistas (PROGRAMA NASCENTES, 2017), reflorestamentos que, como já dito, poderiam contribuir sobremaneira para a captura e fixação do dióxido de carbono existente na atmosfera.

É certo que o Programa Nascentes possui envergadura muito mais ampla que sua meta inicial, visto que, em consulta ao seu site, é possível verificar que o Banco de Áreas hoje existente conta com 3.243 hectares de Áreas de Preservação Permanente a ser recuperada, em 30 municípios, segundo o cadastro realizado junto à Fundação Instituto de Terras - ITESP (PROGRAMA NASCENTES, 2017).

A área total a ser recuperada, na qual estão contidas as Áreas de Preservação Permanente, certamente será ampliada consideravelmente quando do término do prazo para a realização do Cadastramento Ambiental Rural - $\mathrm{CAR}^{13}$, previsto para ocorrer em 31 de dezembro de 2017, com a possibilidade de ser prorrogado para 31 de dezembro de 2018, conforme previsão do Art. 29, §3º, da Lei oㅡ 12.651/12, com redação dada pela Lei oํ 13.295/16.

Tal afirmação tem por esteio a adesão dos proprietários ao Programa de Regularização Ambiental - PRA, conforme previsão do Art. 59, da Lei ํo12.651/12, oportunidade em que assumirão o compromisso de proteger e recuperar as Área de Preservação Permanente e Reservas Legais existentes no interior das propriedades, mediante a assinatura de um termo de

\footnotetext{
12 A denominação mata ciliar refere-se à mata nativa situada ao longo dos cursos d'água, a qual tem como função evitar que impurezas cheguem livremente aos referidos corpos hídricos, assim como os cílios têm a função de evitar que impurezas atinjam livremente os dos olhos humanos. No sentido lato as matas ciliares podem ser entendidas como as Áreas de Preservação Permanente dos recursos hídricos, incluindo-se, então, as matas nativas adjacentes às nascentes, aos olhos d'água, aos cursos d'água etc.

${ }^{13}$ O Cadastramento Ambiental Rural trata-se de uma exigência criada pelo Art. 29, §3ํㅡ, da Lei no $12.651 / 12$, à qual as propriedades e posses rurais situadas em território brasileiro terão que se submeter para que sejam consideradas regularizadas do ponto de vista legal. Consiste em um cadastro nacional informatizado, de propriedades e posses rurais brasileiras, no qual é inserida a "[...] identificação do imóvel por meio de planta e memorial descritivo, contendo a indicação das coordenadas geográficas com pelo menos um ponto de amarração do perímetro do imóvel, informando a localização dos remanescentes de vegetação nativa, das Áreas de Preservação Permanente, das Áreas de Uso Restrito, das áreas consolidadas e, caso existente, também da localização da Reserva Legal" (BRASIL, 2012).
} 
compromisso para regularização de imóvel ou posse rural perante o órgão ambiental competente.

Os recursos da CIDE COMBUSTÍVEL revelam-se como um campo fértil para o financiamento de projetos ou programas ambientais que tenham por finalidade a recuperação das Áreas de Preservação Permanente de recursos hídricos, podendo, desta forma, os governos dos Estados federados, por meio de suas Secretarias Estaduais de Meio Ambiente, pleitearem a destinação de tais recursos para programas estaduais de recuperação de Áreas de Preservação Permanente, principalmente pelo fato de que tal destinação dos recursos viabilizará sobremaneira o alcance da finalidade prevista no Art. 177, §4ํㅜㅇ, inciso II, letra "b", da Constituição Federal de 1988, e no artigo 1ํㅗㅇำ inciso II, da Lei no 10.336/01, além de viabilizar que o Programa de Regularização Ambiental - PRA atinja sua finalidade, qual seja recuperar, em todo o território brasileiro, as Áreas de Preservação Permanente e as Reservas Legais em imóveis e posses rurais, de acordo com as dimensões contidas na Lei $\mathrm{n}^{0}$ $12.651 / 12$.

Outra forma de fomentar a recuperação das Áreas de Preservação Permanente de recursos hídricos seria a realização de uma alteração legislativa, a ser realizado no bojo da Lei no 10.336/01, de forma a inserir o Art. 8-B, permitindo a dedução de valores aplicados, e devidamente comprovados, na recuperação de Áreas de Preservação Permanente de recursos hídricos, por aqueles que atuam na importação e na comercialização de petróleo e seus derivados, gás natural e seus derivados, e álcool etílico combustível ${ }^{14}$

Neste caso, com tal alteração legislativa, no momento da apuração da CIDE COMBUSTÍVEL o contribuinte que comprovar, junto ao Órgão Fiscal, a aplicação de valores para a recuperação de Área de Preservação Permanente, poderá abater o valor aplicado do valor que teria que recolher a título de CIDE COMBUSTIVEL, ou seja, o contribuinte aplicaria diretamente o valor na recuperação da Área de Preservação Permanente e depois, mediante comprovação junto ao Fisco, abateria tal valor do montante que teria que

14 O Art. 8-B poderia ser inserido na Lei no 10.336/01 com a seguinte redação: Art. 8--B. O contribuinte poderá, ainda, deduzir do valor a ser recolhido da CIDE, em virtude da importação ou da comercialização, no mercado interno, os valores aplicados, e devidamente comprovados, na recuperação de Áreas de Preservação Permanente de recursos hídricos. 
recolher a título de CIDE COMBUSTÍVEL, recolhendo apenas o valor da CIDE que exceder ao valor aplicado para a recuperação da Área de Preservação permanente. A comprovação da aplicação de valores na recuperação de Área de Preservação Permanente poderia se dar, por exemplo, por meio da obtenção de declaração de recuperação de Área de Preservação Permanente junto aos órgãos de licenciamento ambiental, a qual deveria ser entregue ao Fisco no momento da apuração e recolhimento da CIDE COMBUSTÍVEL.

Tal alteração legislativa incentivaria a recuperação das Áreas de Preservação Permanente de recursos hídricos, pois além da dedução dos valores aplicados para tal mister, as empresas que atuam na importação e na comercialização de petróleo e seus derivados, gás natural e seus derivados, e álcool etílico combustível poderiam utilizar as informações referentes às recuperações realizadas para comprovar sua boa-fé objetiva no desempenho da atividade econômica, de forma a demonstrar que colabora para o desenvolvimento nacional sustentável, por meio da geração de lucro, alinhada à proteção do equilíbrio ambiental e ao desenvolvimento social.

\section{CONCLUSÃO}

A concepção ampla do que seja extrafiscalidade permite identificá-la não somente na incidência tributária voltada a estimular, induzir ou coibir comportamentos, mas também na destinação específica do produto arrecadado pelas chamadas Contribuições de Intervenção no Domínio Econômico - CIDE, as quais não buscam estimular ou coibir comportamentos, mas sim realizar diretamente valores constitucionais, de acordo com as finalidades constitucionais e/ou legais que justificam a sua criação.

Desta forma, a extrafiscalidade revela-se como um instrumento ímpar de efetivação dos fundamentos e objetivos da República Federativa do Brasil, e deve operar para garantir a observância dos princípios constitucionais em prol da construção de uma sociedade livre, justa e solidária, em um ambiente de desenvolvimento nacional sustentável e de erradicação da pobreza e da marginalização, visando à justiça social, com a redução das 
desigualdades sociais e regionais, como forma de garantir a fruição de uma vida digna de ser vivida.

A exploração dos recursos naturais, o descarte de resíduos sólidos, a emissão de efluentes líquidos e a emissão de gases de efeito estufa, sem limites científicos aptos a evitar o esgotamento dos recursos naturais e a poluição, ou seja, sem limites científicos aptos a garantir o equilíbrio ambiental, gerou uma situação fática de desequilíbrio ambiental, ou seja, de caos ambiental.

A manutenção deste comportamento pelos seres humanos, somada à desigualdade social - distanciamento do equilíbrio social -, foi aumentando a distância entre 0 atendimento das necessidades humanas e o equilíbrio ambiental, de forma a gerar uma situação de caos ambiental, caracterizada pelo desequilíbrio - distanciamento do equilíbrio ambiental -, o qual tem externalizado-se de várias formas, como na poluição do ar, da água e dos solos, na escassez da água potável de fácil acesso, no fenômeno do aquecimento global, na perda da biodiversidade e no esgotamento de jazidas minerais.

A existência de uma vida digna de ser vivida pela atual e pelas futuras gerações depende da adoção de medidas mitigadoras do estado de caos ambiental instalado, para que o equilíbrio ambiental possa ser restaurado e, assim, o direito fundamental de fruição de um meio ambiente ecologicamente equilibrado possa ser garantido.

Desta forma, revela-se de extrema importância a indução, por parte do Estado brasileiro, à recuperação das Áreas de Preservação Permanente de recursos hídricos, como forma de mitigação do caos ambiental instalado.

Neste aspecto, a Contribuição de Intervenção no Domínio Econômico - CIDE pode se revelar como importante instrumento de indução apto a mitigar o caos ambiental instalado, ao menos no que se refere à recuperação das Áreas de Preservação Permanente de recursos hídricos, visando à mitigação das mudanças climáticas, da escassez de água potável de fácil acesso e da perda da biodiversidade, por meio do restabelecimento das funções ambientais de tais áreas.

A CIDE COMBUSTÍVEL representa um instrumento tributário voltado à 
realização das finalidades previstas na Constituição Federal de 1988 e na Lei no 10.336/01. Assim, sua constitucionalidade e legalidade material são vinculadas às finalidades que motivaram a sua criação, dentre elas 0 financiamento de projetos e programas ambientais relacionados com o setor econômico de produção de petróleo e de seus derivados.

Tal finalidade da CIDE COMBUSTÍVEL visa à mitigação das falhas de mercado propiciadas pelo setor econômico de comercialização de petróleo e de seus derivados, mais especificamente das externalidades negativas reveladas nos riscos e danos ambientais decorrentes de tal setor econômico.

Portanto, o financiamento de projetos e programas ambientais relacionados com a indústria do petróleo e de seus derivados, por meio da CIDE COMBUSTÍVEL, alinha-se ao objetivo da República Federativa do Brasil de propiciar um desenvolvimento nacional sustentável, conforme preconizado pela Constituição Federal de 1988, em seus artigos 3o , 170 e 225.

No entanto, os recursos arrecadados pelo Poder Público por meio da CIDE COMBUSTÍVEL não têm atingido integralmente as finalidades para as quais o referido tributo foi criado, visto que uma boa parcela de tais recursos foi utilizada para despesas administrativas não previstas dentre tais finalidades constitucionais e legais.

Com o desvio dos recursos, ou seja, com a não integralização completa dos recursos, há clara inobservância ao contido no Art. 177, §4, inciso II, da Constituição Federal de 1988 e no Art. 1ํㅡㄴ $\S 1^{\circ}$, da Lei ํo 10.336/01, com violação, portanto, das regras de competência que condicionam a criação do respectivo tributo.

Com isso, torna-se ilegal a sujeição do contribuinte ao seu pagamento, vez que o montante exigido não está sendo integralmente utilizado para os fins que justificaram a criação do tributo.

No entanto, tal situação de ilegalidade pode ser revertida, por exemplo, com a destinação dos recursos da CIDE COMBUSTíVEL para a recuperação de Áreas de Preservação Permanente, destinação que atende ao princípio da legalidade, vez que perfeitamente alinhada à finalidade prevista no Art. 177, $\S 4^{\circ}$, inciso II, da Constituição Federal de 1988, e no artigo 1oㅗ $\$ 1$, da Lei $n^{\circ}$ 
$10.336 / 01$.

O financiamento de um projeto ambiental com tal viés teria por base a emissão de gases de efeito estufa promovida por meio da queima do petróleo e de seus derivados, principalmente o dióxido de carbono.

Assim, os recursos da CIDE COMBUSTÍVEL revelam-se como um campo fértil para o financiamento de projetos ou programas ambientais que tenham por finalidade a recuperação das Áreas de Preservação Permanente, podendo, desta forma, os governos dos estados federados, por meio de suas Secretarias Estaduais de Meio Ambiente, pleitearem a destinação de tais recursos para programas estaduais de recuperação de Áreas de Preservação Permanente, principalmente pelo fato de que tal destinação dos recursos viabilizará sobremaneira o atingimento da finalidade prevista no Art. 177, $\$^{\circ}$, inciso II, letra "b", da Constituição Federal de 1988, e no artigo $1^{\circ}$, $§ 1^{\circ}$, inciso II, da Lei no 10.336/01, além de viabilizar que o Programa de Regularização Ambiental PRA atinja sua finalidade, qual seja recuperar, em todo o território brasileiro, as Áreas de Preservação Permanente e as Reservas Legais em imóveis e posses rurais, de acordo com as dimensões contidas na Lei oㅜ 12.651/12.

Nesta linha de raciocínio, também se poderia fomentar a recuperação das Áreas de Preservação Permanente de recursos hídricos por meio de alteração legislativa a ser realizada no bojo da Lei oㅡ 10.336/01, de forma a inserir o Art. 8-B, permitindo a dedução de valores aplicados, e devidamente comprovados, na recuperação de Áreas de Preservação Permanente de recursos hídricos, por aqueles que atuam na importação e na comercialização de petróleo e seus derivados, gás natural e seus derivados, e álcool etílico combustível.

Pode se afirmar, então, que o Estado, na condição de agente regulador da Ordem Econômica, deve editar normas voltadas ao desenvolvimento sustentável, capazes de harmonizar a proteção ao meio ambiente e o desenvolvimento socioeconômico.

\section{BIBLIOGRAFIA}

ATALIBA, Geraldo. IPTU: progressividade. Revista de Direito Público, v. 23, n. 93, pp. 233-238, jan./mar. 1990. 
BARRETO, Paulo Ayres. Contribuições: regime jurídico, destinação e controle. São Paulo: Noeses, 2011.

BRASIL. Constituição Federal de 1988. Disponível em: <http://www.planalto.gov.br/ccivil_03/constituicao/constituicaocompilado.htm>. Acesso em: 19 mar. 2019.

. Lei no 10.336, de 19 de dezembro de 2001. Institui Contribuição de Intervenção no Domínio Econômico incidente sobre a importação e a comercialização de petróleo e seus derivados, gás natural e seus derivados, e álcool etílico combustível (Cide), e dá outras providências. Disponível em: <http://www.planalto.gov.br/ccivil_03/leis/LEIS_2001/L10336.htm>. Acesso em: 19 mar. 2019.

. Decreto $n^{\circ}$ 5.060, de 30 de abril de 2004. Reduz as alíquotas da Contribuição de Intervenção no Domínio Econômico incidente sobre a importação e a comercialização de petróleo e seus derivados, gás natural e seus derivados, e álcool etílico combustível (CIDE), instituída pela Lei no 10.336, de 19 de dezembro de 2001, e dá outras providências. Disponível em: $<$ http://www.planalto.gov.br/ccivil_03/_Ato20042006/2004/Decreto/D5060.htm>. Acesso em: 20 mar. 2019.

. Instrução Normativa SRF no 422, de 17 de maio de 2004. Dispõe sobre a incidência, apuração e exigência da Contribuição de Intervenção no Domínio Econômico instituída pela Lei no 10.336, de 2001 (Cide-Combustíveis). Disponível em: $<$ http://normas.receita.fazenda.gov.br/sijut2consulta/link. action?idAto=15323\&vi sao=original $>$. Acesso em: 19 mar. 2019.

. Decreto $n^{\circ}$ 6.446, de 02 de maio de 2008. Dá nova redação aos incisos I e II do caput do art. 10 do Decreto o 5.060, de 30 de abril de 2004, para reduzir as alíquotas da Contribuição de Intervenção no Domínio Econômico CIDE incidentes sobre a importação e a comercialização de gasolina e suas correntes e diesel e suas correntes. Disponível em: $<$ http://www.planalto.gov.br/ccivil_03/_Ato20072010/2008/Decreto/D6446.htm>. Acesso em: 20 mar. 2019. 
Decreto $n^{\circ} 6.875$, de 08 de junho de 2009. Dá nova redação aos incisos I e II do caput do art. 1ㅇ do Decreto № 5.060, de 30 de abril de 2004, para alterar as alíquotas da Contribuição de Intervenção no Domínio Econômico CIDE incidente sobre a importação e comercialização de gasolina e suas correntes e diesel e suas correntes. Disponível em: <http://www.planalto.gov.br/ccivil_03/_Ato2007-

2010/2009/Decreto/D6875.htm>. Acesso em: 20 mar. 2019.

. Decreto $n^{\circ}$ 7.095, de 04 de fevereiro de 2010. Altera o Decreto o 5.060, de 30 de abril de 2004. Disponível em: <http://www.planalto.gov.br/ccivil_03/_Ato20072010/2010/Decreto/D7095.htm>. Acesso em: 20 mar. 2019.

. Decreto $n^{\circ}$ 7.570, de 26 de setembro de 2011. Altera o Decreto oo 5.060 , de 30 de abril de 2004, que reduz as alíquotas da Contribuição de Intervenção no Domínio Econômico incidente sobre a importação e a comercialização de petróleo e seus derivados, gás natural e seus derivados, e álcool etílico combustível - CIDE. Disponível em: <http://www.planalto.gov.br/ccivil_03/_Ato20112014/2011/Decreto/D7570.htm>. Acesso em: 20 mar. 2019.

. Decreto $n^{\circ} 7.591$, de 28 de outubro de 2011. Dá nova redação ao art. $1^{\circ}$ do Decreto no 5.060 , de 30 de abril de 2004, que reduz as alíquotas da Contribuição de Intervenção no Domínio Econômico incidente sobre a importação e a comercialização de petróleo e seus derivados, gás natural e seus derivados, e álcool etílico combustível - CIDE, e dá outras providências. Disponível em: <http://www.planalto.gov.br/ccivil_03/_Ato20112014/2011/Decreto/D7591.htm>. Acesso em: 20 mar. 2019.

. Lei no 12.651, de 25 de maio de 2012. Dispõe sobre a proteção da vegetação nativa; altera as Leis nos6.938, de 31 de agosto de 1981, 9.393, de 19 de dezembro de 1996, e 11.428, de 22 de dezembro de 2006; revoga as Leis $\mathrm{n}^{\circ} 4.771$, de 15 de setembro de 1965, e $\mathrm{n} \cong 7.754$, de 14 de abril de 1989, e a Medida Provisória no 2.166-67, de 24 de agosto de 2001; e dá outras providências. Disponível em: <http://www.planalto.gov.br/ccivil_03/_ato20112014/2012/lei/l12651.htm>. Acesso em: 19 mar. 2019. 
. Decreto $n^{\circ} 7.764$, de 22 de junho de 2012. Altera o Decreto $n^{\circ} 5.060$, de 30 de abril de 2004, que reduz as alíquotas da Contribuição de Intervenção no Domínio Econômico incidente sobre a importação e a comercialização de petróleo e seus derivados, gás natural e seus derivados, e álcool etílico combustível - CIDE. Disponível em: <http://www.planalto.gov.br/ccivil_03/_Ato20112014/2012/Decreto/D7764.htm>. Acesso em: 20 mar. 2019.

. Decreto $n^{\circ}$ 8.395, de 28 de janeiro de 2015. Altera o Decreto $n=5.059$, de 30 de abril de 2004, que reduz as alíquotas da Contribuição para o PIS/PASEP e da COFINS incidentes sobre a importação e a comercialização de gasolina, óleo diesel, gás liquefeito de petróleo e querosene de aviação, e o Decreto $\mathrm{n}$-5.060, de 30 de abril de 2004, que reduz as alíquotas da Contribuição de Intervenção no Domínio Econômico incidente sobre a importação e a comercialização de petróleo e seus derivados, gás natural e seus derivados e álcool etílico combustível. Disponível em: $<$ http://www.planalto.gov.br/ccivil_03/_Ato2015-

2018/2015/Decreto/D8395.htm>. Acesso em: 20 mar. 2019.

BRASIL. UNICEF. A deterioração da qualidade da água ameaça os avanços globais em relação ao acesso à água potável. 2010. Disponível em: <http://www.unicef.org/brazil/pt/media_17358.htm>. Acesso em: 25 maio 2017.

Alcançado o ODM para água potável. 2012. Disponível em: <http://www.unicef.org/brazil/pt/media_22801.htm>. Acesso em: 25 maio 2017.

- Crianças morrem diariamente devido à falta de água potável, saneamento básico e higiene, diz UNICEF. 2013. Disponível em <http://www.unicef.org/brazil/pt/media_25190.htm>. Acesso em 25 mai 2017.

CALIENDO, Paulo. A Extrafiscalidade como Instrumento de Implementação dos Direitos Fundamentais Sociais no Brasil. Revista Jurídica do CESUCA, v.2, n.4, pp. 61-86, dez/2014.

; MUNIZ, Veyzon. Política fiscal e desenvolvimento tecnológicoempresarial: Uma análise crítica sobre inovação e tributação. Revista de Direito Brasileira, São Paulo, Ano 5, v.12., pp.155-172, 2015. 
CARRAZZA, Roque Antônio. Curso de direito constitucional tributário. São Paulo: Malheiros, 2008.

CARVALHO FILHO, José dos Santos. Manual de Direito Administrativo. 21. ed. revista, ampliada e atualizada até 31/12/2008. Rio de Janeiro: Editora Lumen luris, 2009.

CAVALCANTE, Denise Lucena. Sustentabilidade Financeira em Prol da Sustentabilidade Ambiental. In: GRUPENMACHER, Betina Treiger; CAVALCANTE, Denise Lucena; RIBEIRO, Maria de Fátima; QUEIROZ, Mary Elbe. Novos Horizontes da Tributação: Um diálogo luso-brasileiro. Coimbra: Almedina, 2012. pp. 96-210.

COMPANHIA AMBIENTAL DO ESTADO DE SÃO PAULO. O problema de escassez de água no mundo. [2007?]. Disponível em: http://cetesb.sp.gov.br/aguas-interiores/informacoes-basicas/tpos-de-agua/oproblema-da-escasez-de-agua-no-mundo/. Acesso em: 19 mar. 2019.

DALLAZEM, Dalton Luiz; LIMA JÚNIOR, Joel Gonçalves de. Tributação e Ordem Econômica. In: Caderno da Escola de Direito, Centro Universitário UNIBRASIL, Curitiba, vol. 1, n. 8, Jan/Jul, pp.319-338, 2008.

DANTAS, Karlo Eric Galvão. A vinculação de receitas Pós-Constituição Federal de 1988 - Rigidez ou flexibilidade? O caso da CIDE-Combustível. 84f. Dissertação (Mestrado em Economia), Universidade de Brasília, Brasília/DF, 2008.

FAO. 2011. The state of the world's land and water resources for food and agriculture (SOLAW) - Managing systems at risk. Food and Agriculture Organization of the United Nations, Rome and Earthscan, London, 2011.

FERRAZ, Roberto. Tributação ambientalmente orientada e as espécies tributárias no Brasil. In: TORRES, Heleno Taveira; PIRES, Adilson Rodrigues (Coord.). Princípios de Direito Financeiro e Tributário. Rio de Janeiro: Renovar, 2006. pp.333-353.

FLORES, Joaquín Herrera. A reinvenção dos direitos humanos. GARCIA, Carlos Roberto Diogo; SUXBERGER, Antônio Henrique Graciano; DIAS, Jefferson Aparecido (tradutores). Florianópolis: Fundação Boiteux, 2009. 
GOVERNO DO ESTADO DE SÃO PAULO. Secretaria do Meio Ambiente. Programa Nascentes. Disponível em: $<$ https://www.infraestruturameioambiente.sp.gov.br/programanascentes/>. Acesso em: 19 mar. 2019.

GRECO, Marco Aurélio. Contribuições de intervenção no domínio econômico: parâmetros para a sua criação. In: GRECO, Marco Aurélio (Coord.). Contribuições de intervenção no domínio econômico e figuras afins. São Paulo: Dialética, 2001. pp. 11-31.

JUNIOR, Amandio Almeida; HERNADEZ, Fernando Braz Tangerino. Água Nova realidade. Disponível em: <http://www.agr.feis.unesp.br/avp280601.htm>. Acesso em: 19 mar. 2019.

MASCITTO, Andréa. Consequências jurídico-tributárias do desvio das receitas de contribuições: Análise sob enfoque da CIDE-Combustível. São Paulo: Quartier Latin, 2013.

MAGANHINI, Thaís Bernardes. Do Pagamento dos Serviços Ambientais: Análise dos Fundamentos Jurídicos Sustentáveis. 173 fls. Tese (Doutorado em Direito), Pontifícia Universidade Católica, São Paulo, 2016. Disponível em: <https://tede2.pucsp.br/bitstream/handle/19170/2/Thais\%20Bernardes\%20Mag anhini.pdf>. Acesso em 19 mar. 2019.

MESSIAS, Ewerton Ricardo; SOUZA, Paulo Roberto Pereira de. Financiamento e dano ambiental: A responsabilidade civil das instituições financeiras. Rio de Janeiro: Lumen Juris, 2015.

- Os loteamentos fechados e a atuação social em prol da ordem urbanística. Porto Alegre: Revolução eBook, 2017.

. Introdução aos princípios gerais do Direito Ambiental. 2. ed. Curitiba: Editora Prismas, 2017.

MORIN, Edgar. Introdução ao pensamento complexo. Lisboa: Instituto Piaget, 2001.

NABAIS, Casalta. O dever fundamental de pagar impostos: contributo para a compreensão do estado fiscal contemporâneo. Coimbra: Livraria Almedina, 1998. 
NUNES, Cíntia Bezerra de Melo Pereira; AZEVEdo, Flaviana Marques de. Tributos Ambientais: Uma Análise da Cide combustíveis Incidente nas Atividades Desenvolvidas pela Indústria do Petróleo e do Gás Natural. Direito E-Nergia, vol. 2. Jan-Jul. 2010.

PACE, Ricardo. Contribuições de intervenção no domínio econômico: direito, economia e política. Porto Alegre: Sergio Antonio Fabris, 2011.

PAYÃO, Jordana Viana; RIBEIRO, Maria de Fátima. A Extrafiscalidade Tributária como Instrumento de Proteção Ambiental. Revista do Direito Público, Londrina, v.11, n.3, pp.276-310, dez. 2016.

PIMENTA, Paulo Roberto Lyrio. Perfil constitucional das contribuições de intervenção no domínio econômico. In: GRECO, Marco Aurélio (Coord.). Contribuições de intervenção no domínio econômico e figuras afins. São Paulo: Dialética, 2001. pp. 157-184.

POSNER, Richard A. Values and consequences: As an introduction to economic analysis of law. University of Chicago Law School, John M. Olin law \& Economics Working, Paper n. 53. 2D Series. Chicago: 1998.

RIBEIRO, Maria de Fátima. Reflexos da Tributação no Desequilíbrio da Livre Concorrência. In: GRUPENMACHER, Betina Treiger; CAVALCANTE, Denise Lucena; RIBEIRO, Maria de Fátima; QUEIROZ, Mary Elbe. Novos Horizontes da Tributação: Um diálogo luso-brasileiro. Coimbra: Almedina, 2012. pp. 205323.

SANTI, Eurico Marcos Diniz de. Tributação, Responsabilidade Fiscal E Desenvolvimento: Direito à transparência estudo sobre a destinação da CPMF e da Cide-Combustíveis. Cadernos de Direito da FGV, Estudo 21, São Paulo, v. 5, n. 1, pp. 1-74, jan. 2008.

SEGUNDO, Hugo de Brito Machado. Curso de direito tributário. São Paulo: Malheiros, 1997.

SILVA, Sergio André Rocha Gomes da. A tributação na sociedade de risco. Revista Tributaria e de Finanças Públicas, São Paulo, v. 67, p. 141-179, 2006.

TORRES, Ricardo Lobo. Curso de direito financeiro e tributário. Rio de Janeiro: Renovar, 2001. 
UNEP 2012. The Emissions Gap Report 2012. United Nations Environment Programme (UNEP), Nairobi.

VILANOVA, Lourival. Fundamentos do Estado de Direito. In: VILANOVA, Lourival. Escritos Jurídicos e Filosóficos, v. I. São Paulo: IBET/Axis-Mundi, 2008. p. $413-430$. 